\title{
PRINSIP-PRINSIP HUKUM PERJANJIAN DALAM KESEPAKATAN PARA PIHAK YANG BERSENGKETA ATAS PERMOHONAN INTERVENSI PIHAK KETIGA DALAM UNDANG-UNDANG NOMOR 30 TAHUN 1999 TENTANG ARBITRASE DAN ALTERNATIF PENYELESAIAN SENGKETA
}

\author{
Oleh \\ Maulidiazeta Wiriardi*
}

\begin{abstract}
Abstrak
Lembaga arbitrase sebagai salah satu bentuk lembaga dalam penyelesaian sengketa alternatifmerupakan jawaban atas semakin banyaknya perkara atau sengketa yang dialami antara dua pihak atau lebih baik itu perorangan maupun badan hukum, karena lembaga pengadilan saat ini telah memiliki beban perkara yang melebihi batas, memiliki prosedur dan proses yang sangat birokratis, berjangka waktu lama, biaya mahal, posisi para pihak saling bermusuhan, persidangan dilakukan terbuka untuk umum, dan pengetahuan para hakim yang generalis. intervensi oleh pihak ketiga dalam penyelesaian sengketa di lembaga Arbitrase berbeda dengan apa yang diatur dalam ketentuan Pasal 279-282 Rv, karena selain Pihak Ketiga tersebut harus memiliki kepentingan dalam perkara in casu, juga harus disepakati oleh para pihak yang bersengketa.
\end{abstract}

Kata Kunci: Perjanjian, Arbitrase, Pihak Ketiga

\section{Pendahuluan}

Sebelum diberlakukannya Undang Undang Nomor 30 Tahun 1999 tentang Arbitrase dan Alternatif Penyelesaian Sengketa (selanjutnya disebut UU Nomor 30 Tahun 1999), yang digunakan sebagai dasar penyelesaian sengketa melalui arbitrase di Indonesia adalah ketentuan Pasal 615 sampai dengan Pasal 651 Reglemen Acara Perdata (Reglement op de Rechtsvorerdering / Rv), Pasal 377 Reglemen Indonesia yang diperbarui (Het Herziene Indonesisch
Reglement / HIR) dan Pasal 705 Reglemen Acara untuk Daerah Luar Jawa dan Madura (Rechtsreglement Buitengewesten / RBg). ${ }^{1}$

Alasan digantinya ketentuan lama mengenai arbitrase dengan UU Nomor 30 Tahun 1999 dijelaskan pada penjelasan umum UU Nomor 30 Tahun 1999, yaitu dengan semakin berkembangnya dunia usaha dan perkembangan lalu lintas perdagangan

\footnotetext{
* Zaidun And Partners, diaz.wiriardi@yahoo.com

1 Pusat Pengkajian Hukum dan Mahkamah Agung Republik Indonesia, Arbitrase dan Mediasi, Jakarta, 2003, h. 67
} 
baik nasional maupun internasional serta perkembangan hukum pada umumnya, peraturan yang terdapat dalam $R v$ yang dipakai sebagai pedoman arbitrase sudah tidak sesuai lagi sehingga perlu disesuaikan, karena pengaturan dagang yang bersifat internasional sudah merupakan kebutuhan conditiosine qua non sedangkan hal tersebut tidak diatur dalam $R v{ }^{2}$

Untuk menyelesaikan sengketa di lembaga arbitrase, para pihak dalam sengketa harus mengadakan perjanjian arbitrase. UU Nomor 30 Tahun 1999 merumuskan suatu perjanjianarbitrasesebagaiperjanjiantertulis untuk menyerahkan sengketa/perbedaan yang timbul sekarang atau yang akan datang kepada arbitrase. ${ }^{3}$ Adanya perjanjian arbitrase tertulis, berarti meniadakan hak para pihak untuk mengajukan penyelesaian sengketa atau beda pendapat yang dimuat dalam perjanjian pokok ke pengadilan negeri. Demikian juga kiranya pengadilan negeri tidak berwenang untuk mengadili sengketa para pihak yang telah terikat dalam perjanjian arbitrase. Ini berarti perjanjian arbitrase melahirkan kompetensi absolut bagi para pihak untuk menentukan sendiri cara penyelesaian sengketa yang dikehendakinya. ${ }^{4}$

Perjanjian arbitrase dapat berupa pactum de compromitendo atau berupa akta kompromis. Pactum de compromitendo memberikan makna bahwa pada saat membentuk perjanjian utama, para pihak

\footnotetext{
2 Gunawan Widjaja dan Ahmad Yani, Hukum Arbitrase, RajaGrafindo Persada, Jakarta, 2000, h. 6

3 Priyatna Abdurrasyid, Arbitrase dan Alternatif Penyelesaian Sengketa, Fikahati Aneska, Jakarta, 2002, h. 91

4 Gunawan Widjaja dan Ahmad Yani, op. cit., h. 46
}

saling menyadari bahwa dalam pelaksanaan perjanjian yang mereka sepakati itu mereka menghadapi resiko terhentinya pelaksanaan perjanjian karena tidak jelasnya syarat tertentu dalam perjanjian, atau munculnya keadaan-keadaan baru sebelum perjanjian dilaksanakan secara sempurna dan keadaankeadaan baru itu dapat berpengaruh pada pelaksanaan perjanjian ke arah yang tidak dikehendaki oleh para pihak, atau ketidaksesuaian para pihak terhadap penilaian apakah prestasi telah dilaksanakan sebagaimana seharusnya dan sebagainya, oleh sebabitu perjanjian arbitrase pun tunduk padaketentuan dan prinsip hukum perjanjian. Artinya sebuah perjanjian arbitrase harus mengikuti azas-azas yang berkembang dalam hukum perjanjian, antara lain azas kebebasan berkontrak, azas pacta sunt servanda, azas itikad baik, dan azas privity of contract, sehingga berdasarkan uraian diatas maka rumusan masalah yang hendak diteliti adalah mengenai prinsip-prinsip hukum perjanjian dalam kesepakatan para pihak yang bersengketa atas permohonan intervensi pihak ketiga sebagaimana yang telah diatur dalam ketentuan Pasal 30 UU Nomor 30 Tahun 1999.

\section{Pembahasan}

Perjanjian merupakan salah satu sumber yang bisa menimbulkan perikatan. ${ }^{5}$ Adapun pengertian dari perikatan adalah suatu perhubungan hukum antara dua orang atau dua pihak, berdasarkan mana pihak yang satu berhak menuntut sesuatu hal

\footnotetext{
5 Dalam ketentuan pasal 1233 BW disebutkan : "Tiap-tiap perikatan dilahirkan karena persetujuan, baik karena undang-undang."
} 
dari pihak yang lain, dan pihak yang lain berkewajiban untuk memenuhi tuntutan itu. ${ }^{6}$ Meskipun bukan yang paling dominan, namun pada umumnya perikatan yang lahir dari perjanjian merupakan yang paling banyak terjadi dalam kehidupan manusia sehari - hari, dan yang juga ternyata banyak dipelajari oleh ahli hukum, serta dikembangkan secara luas oleh legislator, para praktisi hukum, serta juga pada cendekiawan hukum, menjadi aturan-aturan hukum positif yang tertulis, yurisprudensi dan doktrin - doktrin hukum yang dapat kita temui dari waktu ke waktu. ${ }^{7}$

Istilahovereenskomst (bahasa Belanda), contract, agreement (bahasa Inggris), contract, convention (bahasa Prancis), pacte, conventie, contractus (bahasa Latin), kontrakt, vertrag (bahasa Jerman), dan sebagainya yang merupakan istilah yang dalam hukum kita dikenal sebagai "kontrak" atau "perjanjian". BW menggunakan istilah overeenkomst dan contract untuk pengertian yang sama. Hal ini dapat dilihat jelas dari judul Bab II Buku III BW. Judul dari Bab II Buku III BW adalah "Tentang Perikatan - Perikatan yang Dilahirkan dari Kontrak atau Perjanjian". Dari judul tersebut dapat diberikan makna bahwa kontrak adalah perjanjian, dan perjanjian adalah kontrak. ${ }^{8}$

Sementara itu banyak kalangan berpendapat sama sebagaimana Subekti berpendapat, bahwa "kontrak adalah

${ }^{6}$ R. Subekti, Hukum Perjanjian, Intermasa, Jakarta, 2008, h. 1

7 Kartini Muljadi dan Gunawan Widjaja, Perikatan Yang Lahir Dari Perjanjian, Raja Grafindo Persada, Jakarta, 2003, h. 1

8 F. X. Suhardana, Contract Drafting : Kerangka Dasar dan Teknik Penyusunan Kontrak, Universitas Atma Jaya, Yogyakarta, 2008, h. 8 perjanjian yang tertulis" dan justru pengertian yang terakhir inilah yang jamak diterima dalam pergaulan hidup bermasyarakat. Kenyataan ini, menurut hukum logika dikenal sebagai kesalahan logis (fallacy of relevance) jenis argumentum ad verecvundian, yaitu penalaran yang mendasarkan atau yang menggantungkan pada pendapat orang yang memiliki otoritas. Hukum perjanjian mempunyai azas - azas umum / prinsip - prinsip yang harus ditaati oleh para pihak yang terlibat didalamnya, yaitu pihak - pihak dalam perjanjian itu sendiri, pihak ketiga, para pelaksana atau aparat penegak hukum termasuk para hakim yang memeriksa dan mengadili perkara - perkara yang berhubungan dengan perjanjian. Azas - azas hukum perjanjian tersebut antara lain, azas kebebasan berkontrak, azas konsensualisme, azas pacta sunt servanda, azas itikad baik, dan azas privity of contract. ${ }^{9}$

Ketentuan Pasal 30 UU Nomor 30 Tahun 1999 dimuat ketentuan bahwa pihak ketiga di luar perjanjian arbitrase dapat turut serta dan melibatkan diri dalam proses penyelesaian sengketa melalui arbitrase, apabila terdapat unsur kepentingan yang terkait dan keturutsertaannya disepakati oleh para pihak yang bersengketa serta disetujui oleh arbiter atau majelis arbitrase yang memeriksa sengketa yang bersangkutan. Unsur kesepakatan para pihak yang bersengketa sebagai unsur bagi pihak ketiga untuk masuk dalam penyelesaian sengketa di arbitrase merupakan sebuah

${ }^{9}$ Paulus J. Soepratignja, Teknik Pembuatan Akta Kontrak, Universitas Atma Jaya, Yoogyakarta, 2007, h. 5 
perjanjian yang selayaknya juga tunduk pada prinsip - prinsip hukum perjanjian. Bahwa kesepakatan yang dibuat oleh para pihak yang bersengketa tersebut merupakan sebuah kesepakatan yang mengikat kepada pihak ketiga yang berkepentingan. Dengan demikian unsur kesepakatan para pihak yang bersengketa dalam intervensi pihak ketiga di arbitrase merupakan unsur yang dapat merugikan pihak ketiga. Hal tersebut dapat terjadi jika para pihak yang bersengketa di arbitrase melakukan persekongkolan / kolusi yang dapat merugikan pihak ketiga, dengan melakukan kesepakatan yang tidak memperbolehkan pihak ketiga masuk dalam penyelesaian sengketa meskipun pihak ketiga tersebut memiliki kepentingan dalam sengketa tersebut.

Bahwa mengenai sebuah perjanjian / kesepakatan yang mengikat bagi pihak ketiga diatur dalam ketentuan Pasal 1317 BW yang lebih dikenal dengan "pengecualian terhadap privity of contract". Adapun ketentuan dalam Pasal 1317 BW menyatakan dapat diadakan perjanjian untuk kepentingan orang ketiga, bila suatu perjanjian yang dibuat untuk diri sendiri, atau suatu pemberian kepada orang lain, mengandung syarat semacam itu. Lebih lanjut ditentukan bahwa siapa pun yang telah menentukan suatu syarat, tidak boleh menariknya kembali, jika pihak ketiga telah menyatakan akan mempergunakan syarat itu.

Lalu dalam hal - hal apa perjanjian menciptakan perikatan demi kepentingan atau beban pihak ketiga? Ternyata hukum lebih toleran terhadap kemungkinan pembuatan perjanjian yang memberikan hak - hak kepada pihak ketiga daripada kemungkinan membebani pihak ketiga dengan kewajiban - kewajiban. ${ }^{10}$ Pendapat tersebut sejalan dengan pendapat A. James Barnes yang menyatakan, "if the parties to the contract intended to benefit a third party, however, the third party can enforce the contract". ${ }^{11}$ Adapun syarat - syarat sahnya janji demi kepentingan pihak ketiga adalah :

1. Tujuan perjanjian antara stipulator (pihak yang memperjanjikan suatu prestasi untuk pihak ketiga dari pihak lawannya) dan promissor (pihak yang mengikatkan diri untuk melakukan prestasi terhadap pihak ketiga) haruslah untuk menimbulkan hak tagihan yang mandiri bagi pihak ketiga.

2. Hak pihak ketiga harus dipadukan dengan suatu hak yang diperjanjikan oleh stipulator untuk dirinya sendiri, atau dengan pemberian dari stipulator kepada promissor.

Berdasarkan hal - hal tersebut dapat diambil kesimpulan bahwa berdasarkan prinsip hukum perjanjian, sebuah perjanjian tidak boleh membawa kerugian bagi pihak ketiga sebagaimana tersirat dalam ketentuan Pasal $1317 B W$. Sehingga unsur kesepakatan para pihak yang bersengketa sebagai syarat pihak ketiga untuk melakukan intervensi dalam penyelesaian sengketa di arbitrase merupakan sebuah syarat / ketentuan yang bertentangan dengan prinsip hukum perjanjian, utamanya prinsip bahwa sebuah

\footnotetext{
10 J. H. Nieuwenhuis, op. cit., h. 107

11 A. James Barnes, op. cit., h. 290
} 
perjanjian tidak dapat membawa kerugian kepada pihak ketiga. Karena dengan adanya unsur tersebut, akan menimbulkan potensi dirugikannya pihak ketiga yang berkepentingan untuk ikut dalam proses pemeriksaan perkara, jika para pihak yang bersengketa bersepakat untuk tidak memperbolehkan pihak ketiga melakukan intervensi.

Prinsip sebuah perjanjian tidak dapat membawa kerugian terhadap pihak ketiga sejalan dengan pendapat Roscoe Pound, yang berpendapat bahwa keadilan menghendaki agar tiap orang dibebaskan untuk memakai kekuasaan alamiah dengan merdeka dalam melakukan penawaran dengan pertukaran serta mengadakan janji, kecuali jika ia menganggu tindakan serupa yang dilakukan oleh orang lain, atau mengganggu beberapa hak asasi orang lain itu. ${ }^{12}$ Dalam pendapatnya tersebut, Roscoe Pound menekankan bahwa setiap orang berkuasa untuk melakukan perjanjian selama tidak melanggar hak orang lain, atau dengan kata lain selama perjanjian tersebut tidak memberikan kerugian terhadap hak dan kepentingan orang lain.

Prinsip sebuah perjanjian tidak boleh membawa kerugian kepada pihak ketiga ini juga diintrodusir dalam hukum persaingan usaha. Dalam Undang Undang Nomor 5 Tahun 1999 Tentang Larangan Praktek Monopoli Dan Persaingan Usaha Tidak Sehat (selanjutnya disebut UU Nomor 5 Tahun 1999), terdapat 11 (sebelas) macam perjanjian yang dilarang untuk dibuat

${ }^{12}$ Roscoe Pound, Pengantar Filsafat Hukum, terjemahan Mohamad Radjab, Bhratara Karya Aksara, Jakarta, 1982, h. 161 oleh pelaku usaha dengan pelaku usaha lain, sebagaimana diatur dalam ketentuan Pasal 4 sampai dengan ketentuan Pasal 16. Perjanjian - perjanjian yang dilarang dibuat tersebut dianggap sebagai praktik monopoli dan / atau persaingan usaha yang tidak sehat. Salah satu contoh perjanjian dalam UU Nomor 5 Tahun 1999 yang dilarang dibuat karena merugikan pihak ketiga adalah pemboikotan.

Pemboikotan ini merupakan perjanjian horizontal antara pelaku usaha pesaing untuk menolak mengadakan hubungan dagang dengan pelaku usaha lain. Larangan mengenai permboikotan ini terdapat dalam ketentuan Pasal 10 UU Nomor 5 Tahun 1999 yang mengatur bahwa pelaku usaha dilarang membuat perjanjian dengan pelaku usaha pesaingnya yang dapat menghalangi pelaku usaha lain untuk melakukan usaha yang sama, baik untuk tujuan pasar dalam negeri maupun pasar luar negeri. Lebih lanjut dalam ayat (2) diatur bahwa pelaku usaha dilarang membuat perjanjian dengan pelaku usaha pesaingnya untuk menolak menjual setiap barang dan / atau jasa dari pelaku usaha lain, sehingga perbuatan tersebut merugikan atau dapat diduga merugikan pelaku usaha lain, atau membatasi pelaku usaha lain dalam menjual atau membeli setiap barang dan / atau jasa dari pasar bersangkutan.

Dari contoh perjanjian yang dilarang dalam ranah hukum persaingan usaha tersebut, dapat diambil kesimpulan bahwa dilarangnya perjanjian pemboikotan merupakan bentuk perlindungan hukum kepada pihak ketiga, karena perjanjian pemboikotan merugikan atau setidaknya 
diduga dapat merugikan pihak lain. Bahwa dengan diintrodusirnya prinsip sebuah perjanjian tidak boleh membawa kerugian pihak ketiga ke dalam hukum persaingan usaha menunjukkan bahwa prinsip tersebut merupakan sebuah prinsip umum yang harus diikuti oleh setiap perjanjian yang dibuat, termasuk namun tidak terbatas pada kesepakatan para pihak yang bersengketa sebagai syarat pihak ketiga untuk melakukan intervensi dalam penyelesaian sengketa di arbitrase yang juga wajib menerapkan prinsip ini, yaitu sebuah perjanjian tidak boleh membawa kerugian kepada pihak ketiga.

Bahwa selain bertentangan dengan prinsip perjanjian tidak boleh membawa kerugian kepada pihak ketiga, unsur kesepakatan para pihak yang bersengketa sebagai unsur bagi pihak ketiga untuk masuk dalam penyelesaian sengketa di arbitrase juga bertentangan dengan azas itikad baik. Dimana telah dijelaskan sebelumnya, sebagaimana ketentuan Pasal $1338 \mathrm{BW}$, sebuah perjanjian wajib dilakukan berdasarkan itikad baik, yaitu kepatutan dan kepantasan. Kepatutan dan kepantasan dalam konteks ini adalah dengan tidak menghalang - halangi pihak ketiga diluar pihak yang bersengketa dalam sengketa di arbitrase untuk melakukan intervensi dalam proses pemeriksaan. Dimana bentuk tindakan para pihak yang bersengketa merupakan tindakan yang menghalang - halangi adalah dengan melakukan perjanjian yang menyepakati pihak ketiga tidak dapat melakukan intervensi atas proses pemeriksaan, walaupun pihak ketiga tersebut memiliki kepentingan, sehingga akan menimbulkan kerugian bagi pihak ketiga karena tidak dapat mempertahankan hak dan kepentingannya.

Walaupun kesepakatan yang demikian itu merupakan hak prerogatif yang diberikan oleh undang - undang kepada para pihak yang bersengketa di arbitrase, tentu hal ini tidak serta merta dapat dibenarkan mengingat kedudukan dari azas hukum itu sendiri. Menurut Sudikno Mertokusumo, azas hukum merupakan pikiran dasar yang umum dan abstrak, atau merupakan latar belakang peraturan konkrit yang terdapat dalam dan di belakang setiap sistem hukum yang terjelma dalam peraturan perundang - undangan dan putusan hakim yang merupakan hukum positif dan dapat diketemukan dengan mencari sifat - sifat atau ciri - ciri yang umum dalam peraturan konkrit tersebut. ${ }^{13}$ Sedangkan menurut van Eikema Hommes, azas hukum perlu dipandang sebagai dasar - dasar umum atau petunjuk - petunjuk bagi hukum yang berlaku. Pembentukan hukum praktis perlu berorientasi pada azas - azas hukum tersebut. Dengan kata lain azas hukum ialah dasar - dasar atau petunjuk arah dalam pembentukan hukum positif. ${ }^{14}$ Dengan demikian dapat disimpulkan bahwa azas hukum dapat mengoreksi dan meluruskan sebuah aturan hukum konkrit yang bertentangan dengan azas hukum itu sendiri, dan seyogyanya aturan hukum konkrit harus mengimplementasikan azas - azas hukum. Dalam UU Nomor 30 Tahun 1999 tidak terdapat ketentuan yang

${ }^{13}$ Sudikno Mertokusumo, Penemuan Hukum, Universitas Atma Jaya Yogyakarta, Yogyakarta, 2010, h. 7

${ }^{14}$ Ibid, h. 6 
mengatur mengenai upaya hukum yang dapat ditempuh oleh pihak ketiga apabila dirugikan oleh sebuah putusan arbitrase. Adapun upaya hukum atas putusan arbitrase dalam UU Nomor 30 Tahun 1999 terdapat dalam ketentuan Pasal 30, yaitu apabila putusan arbitrase mengandung unsur unsur sebagai berikut :

1. Surat atau dokumen yang diajukan dalam pemeriksaan, setelah dijatuhkan putusan, diakui palsu atau dinyatakan palsu;

2. Setelah putusan diambil ditemukan dokumen yang bersifat menentukan, yang disembunyikan oleh pihak lawan;

3. Putusan diambildarihasil tipu muslihat yang dilakukan oleh salah satu pihak dalam pemeriksaan sengketa

Akan tetapi upaya hukum tersebut merupakan upaya hukum salah satu pihak yang bersengketa dalam perkara yang diputus tersebut. Sehingga pihak ketiga yang dirugikan hak dan kepentingannya oleh suatu putusan arbitrase tidak dapat mengajukan pembatalan atas putusan arbitrase. Selain itu, sama halnya dengan ketentuan dalam UU Nomor 30 Tahun 1999, dalam ketentuan di $R v$ tidak ada pengaturan mengenai upaya hukum yang dapat ditempuh oleh pihak ketiga. Bahwa mengenai upaya hukum pihak ketiga yang dirugikan hak dan kepentingannya, Tin Zuraida dalam bukunya memberikan sebuah kasus yang pernah terjadi, yaitu pada tanggal 1 Nopember 1990, PT Cellfone Nusantara selaku penjual melawan perusahaan Okeanis
Shipping Limited, London, selaku pembeli, yang telah sepakat membuat perjanjian jual beli 5 (lima) buah kapal yang masih dikuasai oleh Pertamina dengan harga US\$ 3.750.000 (tiga juta tujuh ratus lima puluh ribu dollar Amerika). Dalam perjanjian tertanggal 1 Nopember 1990 tersebut telah diperjanjikan tentang klausula arbitrase, yakni jika terjadi sengketa antara kedua belah pihak akan diselesaikan pada arbitrase London (Pasal 15 perjanjian a quo).

Karena terjadi ingkar janji, pihak pembeli (Okeanis Shipping Limited) mengajukan perkara ke arbitrase di London pada tanggal 4 Nopember 1998 dan telah diputus dengan menghukum pihak penjual (PT Cellfone Nusantara) untuk membayar ganti kerugian kepada pihak Okeanis Shipping Limited sebesar US\$ 1.000.000 (satu juta dollar Amerika) dengan bunga sebesar $8 \%$ per tahun.

Putusan arbitrase internasional tersebut telah didaftarkan pada Kedutaan Besar Republik Indonesia di London pada tanggal 27 September 2000. Kemudian putusan tersebut telah didaftarkan Kepaniteraan Pengadilan Negeri Jakarta Pusat berdasarkan permohonan pemohon melalui kuasa dari Arbiter Internasional di London dengan Nomor Registrasi Perkara : 001/ Pdt/Arb.Int1/2001/PN.Jkt.Pst, tanggal 15 Pebruari 2001. Kemudian pada tanggal 26 Pebruari 2001, kuasa dari Okeanis Shipping Limited telah mengajukan permohonan untuk diberikannya eksekuatur pada Ketua Pengadilan Negeri Jakarta Pusat. Setelah dilakukan penilaian dan penelitian dengan seksama Ketua Pengadilan Negeri Jakarta 
Pusat mengabulkan permohonan eksekuatur atas putusan arbitrase internasional tersebut dengan mengeluarkan Penetapan Nomor : 035/2001 Eks. tanggal 16 April 2001.

Pada tanggal 11 Juli 2001 atas permohonan dari pemohon, Ketua Pengadilan Negeri Jakarta Pusat berdasarkan Penetapan Nomor : 035/2001 Eks., tanggal 17 April 2001 telah melakukan peringatan / tegoran / aanmaning terhadap termohon agar mau melaksanakan secara sukarela putusan arbitrase internasional tersebut. Akan tetapi karena termohon tidak memenuhi, selanjutnya diletakkan sita eksekusi dengan meminta bantuan delegasi Ketua Pengadilan Negeri Jakarta Selatan atas sebidang tanah dan bangunan milik termohon yang terletak di Jalan Gabus Nomor 36 Kav. 5, Pasar Minggu, Jakarta Selatan, sesuai dengan penetapan Nomor : 28/Del/2001/PN.Jkt.Sel. Selanjutnya pada tanggal 24 Agustus 2001 Ketua Pengadilan Negeri Jakarta Pusat berdasarkan Penetapan Nomor : 035/2001 Eks., dengan meminta bantuan kepada Ketua Pengadilan Negeri Jakarta Selatan memerintahkan untuk melaksanakan eksekusi lelang terhadap barang milik termohon.

Termohon eksekusi kemudian pada tanggal 17 Oktober 2001 mengajukan permohonan penundaan / penangguhan eksekusi dengan alasan adanya perlawanan pihak ketiga (derden verzet) dengan Nomor : 477/Pdt.G/2001/PN.Jkt.Pst., sehingga kemudian Ketua Pengadilan Negeri Jakarta Pusat berdasarkan Penetapan Nomor : 035/2001 Eks., tanggal 29 Oktober 2001 mengabulkan penundaan / penangguhan eksekusi tersebut. Pada tanggal 12 September 2002 majelis hakim dalam perkara perlawanan pihak ketiga dengan Nomor : 477/Pdt.G/2001/PN.Jkt.Pst., telah memutus bahwa pelawan bukan pelawan yang baik sehingga perlawanan pun ditolak. Selanjutnya pemohon mengajukan permohonan eksekusi kembali, Ketua Pengadilan Negeri Jakarta Pusat berdasarkan Penetapan Nomor:035/2001 Eks., tanggal 27 Pebruari 2003 mencabut dan membatalkan penetapan penundaan tertanggal 29 Oktober 2001 untuk dilanjutkan kembali. Pada tanggal 2 Juni 2003 telah diselenggarakan eksekusi lelang atas barang milik termohon berupa tanah dan bangunan dengan hasil pelelangan sebesar Rp. 1.135.000.000,00 (satu milyar seratus tiga puluh lima juta rupiah) setelah dikurangi biaya lelang. ${ }^{15}$

Bahwa berdasarkan kasus yang pernah terjadi diatas, pihak ketiga yang merasa dirugikan oleh putusan arbitrase dapat melakukan mekanisme perlawanan pihak ketiga (derden verzet). Hal ini dikarenakan ketentuanumumhukumacaraperdataberlaku juga pada hukum acara arbitrase, selama tidak bertentangan dengan UU Nomor 30 Tahun 1999. Atas upaya perlawanan pihak ketiga dalam perkara tesebut, pelawan harus dapat membuktikan bahwa ia mempunyai alas hak atas barang yang disita dan pelawan tersebut akan dinyatakan sebagai pelawan yang benar dan sita akan diperintahkan untuk diangkat apabila pelawan tersebut berhasil membuktikan ia memiliki alas hak atas barang yang disita. Dan apabila pelawan tidak dapat membuktikan bahwa ia

\footnotetext{
15 Tin Zuraida, op. cit., h. 300
} 
adalah pemilik dari barang yang disita maka pelawan akan dinyatakan sebagai pelawan yang tidak benar atau pelawan yang tidak jujur, dan sita akan dipertahankan. Selain itu patut untuk diperhatikan bahwa perlawanan pihak ketiga terhadap sita eksekusi atau sita jaminan tidak hanya dapat diajukan atas dasar hak milik, tetapi juga dapat didasarkan pada hak - hak lainnya, seperti hak pakai, HGB, HGU, hak tanggungan, hak sewa, dan lain - lain.

Upaya hukum pihak ketiga dalam contoh kasus diatas bertentangan dengan ketentuan Pasal 196 ayat (6) HIR, karena dalam perkara tersebut, pihak ketiga mengajukan perlawanan pihak ketiga bukan kepada Ketua Pengadilan Negeri Jakarta Selatan yang menjalankan perintah eksekusi, namun kepada Ketua Pengadilan Negeri Jakarta Pusat sebagai pengadilan yang mengeluarkan perintah eksekusi. Upaya hukum perlawanan oleh pihak ketiga seharusnya diajukan kepada pengadilan negeri yang menjalankan eksekusi, sebagaimana ketentuan Pasal 196 ayat (1) HIR yang memuat ketentuan bahwa perlawanan terhadap eksekusi suatu putusan diajukan kepada pengadilan negeri yang menjalankan eksekusi, bukan kepada pengadilan negeri yang mengeluarkan perintah eksekusi. Dalam konkreto, tidak selamanya eksekusi dijalankan oleh pengadilan negeri yang mengeluarkan perintah eksekusi. Adakalanya barang yang hendak dieksekusi terletak di wilayah hukum pengadilan negeri yang lain, sehingga pelaksanaan eksekusi "didelegasikan" oleh pengadilan negeri yang mengeluarkan perintah eksekusi kepada pengadilan negeri ditempat mana barang terletak. ${ }^{16}$ Menurut Retnowulan, persoalan kewenangan relatif berkaitan dengan perlawanan pihak ketiga sering nampak belum dipahami benar. Meskipun "agak terselubung", telah diatur dalam pasal tersebut bahwa perlawanan dari pihak ketiga diajukan kepada pengadilan negeri yang dalam daerah hukumnya terjadi hal menjalankan putusan itu. Perlawanan tersebut juga diputuskan oleh pengadilan negeri yang menjalankan eksekusi. ${ }^{17}$

\section{Penutup}

Unsur kesepakatan para pihak yang bersengketasebagaisyarat pihakketigauntuk melakukan intervensi dalam penyelesaian sengketa di arbitrase merupakan sebuah syarat / ketentuan yang bertentangan dengan prinsip hukum perjanjian, yaitu prinsip bahwa sebuah perjanjian tidak boleh membawa kerugian bagi pihak ketiga sebagaimana tersirat dalam ketentuan Pasal $1317 \mathrm{BW}$ dan prinsip itikad baik sebagaimana dimaksud dalam ketentuan Pasal $1338 \mathrm{BW}$. Karena dengan adanya unsur tersebut, akan menimbulkan potensi dirugikannya pihak ketiga yang berkepentingan untuk ikut dalam proses pemeriksaan perkara, jika para pihak yang bersengketa bersepakat untuk tidak memperbolehkan pihak ketiga melakukan intervensi.

Sehingga tidak ada ketentuan yang mengatur secara khusus mengenai upaya hukum yang dapat ditempuh oleh pihak

\footnotetext{
${ }^{16}$ M. Yahya Harahap, Arbitrase, Sinar Grafika, Jakarta, 2003, h. 281

${ }_{17}$ RetnowulanSutantiodanIskandarOeripkartawinata, op. cit., h. 181
} 
ketiga dalam ketentuan Undang Undang Nomor 30 Tahun 1999 Tentang Arbitrase Dan Alternatif Penyelesaian Sengketa. Namun ketentuan dalam hukum acara perdata juga berlaku pada hukum acara arbitrase, sehingga pihak ketiga yang dirugikan atas putusan arbitrase yang melanggar hak dan kepentingannya dapat mengajukan perlawanan pihak ketiga pada pengadilan negeri yang akan melaksanakan eksekusi atas putusan arbitase tersebut.

Oleh karena itu perlu dilakukan perubahan atas ketentuan Pasal 30 UU Nomor 30 Tahun 1999 yang memuat unsur kesepakatan para pihak yang bersengketa dalam intervensi pihak ketiga di arbitrase. Sehingga masuknya pihak ketiga dalam suatu proses pemeriksaan perkara tidak perlu mendapat kesepakatan para pihak yang bersengketa, namun cukup dengan putusan sela dari arbiter / majelis arbiter sebagaimana badan peradilan lainnya dan perlu diatur pula secara khusus mengenai bentuk perlindungan hukum kepada pihak ketiga yang dirugikan atas putusan arbitrase. Hal tersebut diperlukan untuk menjamin kepastian hukum bagi pihak - pihak diluar proses pemeriksaan perkara di arbitrase, yang dirugikan hak dan kepentingannya.

\section{Daftar Bacaan}

Pusat Pengkajian Hukum dan Mahkamah Agung Republik Indonesia, Arbitrase dan Mediasi, Jakarta, 2003.

Gunawan Widjaja dan Ahmad Yani, Hukum Arbitrase, RajaGrafindo Persada, Jakarta, 2000.
Priyatna Abdurrasyid, Arbitrase dan Alternatif Penyelesaian Sengketa, Fikahati Aneska, Jakarta, 2002.

R. Subekti, Hukum Perjanjian, Intermasa, Jakarta, 2008.

Kartini Muljadi dan Gunawan Widjaja, Perikatan Yang Lahir Dari Perjanjian, Raja Grafindo Persada, Jakarta, 2003.

F. X. Suhardana, Contract Drafting : Kerangka Dasar dan Teknik Penyusunan Kontrak, Universitas Atma Jaya, Yogyakarta, 2008.

Paulus J. Soepratignja, Teknik Pembuatan Akta Kontrak, Universitas Atma Jaya, Yoogyakarta, 2007.

Roscoe Pound, Pengantar Filsafat Hukum, terjemahan Mohamad Radjab, Bhratara Karya Aksara, Jakarta, 1982.

Sudikno Mertokusumo, Penemuan Hukum, Universitas Atma Jaya Yogyakarta, Yogyakarta, 2010.

M. Yahya Harahap, Arbitrase, Sinar Grafika, Jakarta, 2003.

Retnowulan Sutantio dan Iskandar Oeripkartawinata, Hukum Acara Perdata Dalam Teori dan Praktek, Mandar Maju, Bandung, 2005. 